\title{
The Digital Divide and K-12 Student Computer Use
}

\author{
James N. Morgan and Craig A. VanLengen \\ Northern Arizona University, Flagstaff, AZ, USA
}

\section{James.Morgan@nau.edu Craig.Vanlengen@nau.edu}

\begin{abstract}
The divide between those who have computer and Internet access and those who do not appears to be narrowing, however overall statistics may be misleading. Measures of computer availability in schools often include cases where computers are only available for administration or are available only on a very limited basis (Gootman, 2004). Access to a computer and the Internet outside of school helps to reinforce student learning and emphasize the importance of using technology. Recent U.S. statistics indicate that ethnic background and other demographic characteristics still have substantial impact on the availability and use of computers by students outside of the classroom. This paper examines recent census data to determine the impact of the household on student computer use outside of the classroom. Encouragingly, the findings of this study suggest that use of a computer at school substantially increases the chance that a student will use a computer outside of class. Additionally, this study suggests that computer use outside of the classroom is positively and significantly impacted by being in a household with adults who either use a computer at work or work in an industry where computers are extensively used.
\end{abstract}

Keywords: Digital-divide, education, K-12 education, Computer use, Internet access

\section{Introduction}

Computer use and the digital divide has been a controversial topic in the United States of America in recent years. The National Telecommunications and Information Administration (NTIA), based on surveys conducted in the mid and latter 1990s, described the U.S.A. as "a nation divided" with respect to the use of computers and the internet ("Falling," 1999, 2000). This assertion was based upon substantial differences observed in the rate of computer use across households by income level and across various demographic categories. Kretchmer and Carveth (2001) report that international scholars may have difficulty understanding the differences in computer and Internet access based on race. Many individuals have not observed the racial discrimination that has been part of public education in the U.S.A.

Following a similar study in 2001, the NTIA, in essence, declared victory - describing the U.S.A. as, "a nation online" ("A Nation," 2002). Substantial increases in the rate of computer use among low income households and rates of computer use in kindergarten through high school (K-12)

Material published as part of this journal, either on-line or in print, is copyrighted by Informing Science. Permission to make digital or paper copy of part or all of these works for personal or classroom use is granted without fee provided that the copies are not made or distributed for profit or commercial advantage AND that copies 1) bear this notice in full and 2) give the full citation on the first page. It is permissible to abstract these works so long as credit is given. To copy in all other cases or to republish or to post on a server or to redistribute to lists requires specific permission from the publisher at Publisher@InformingScience.org schools nearing 90 percent were cited in support of this conclusion.

Despite the trends cited above, substantial differences in the rate of computer ownership across demographic groups persisted in the 2001 survey (“A Nation," 2002). Some researchers have attributed digital differences in 
home computer access to the perceived importance and desirability (preference) of computer use across varied demographic groups (Compaine, 2001). However, others have expressed concern that the poor lack meaningful access to computer and Internet use when compared to access for those at higher income levels (Attewell, 2001; "Computer," 2003; Mack, 2001). This would indicate that the digital divide is based on differing abilities to gain access. A report by several consumer groups showed that households with an income level greater than $\$ 50,000$ were three times more likely to be connected to the Internet than households with incomes less than $\$ 15,000$ ("Digital," 2002).

A recent study released by the U.S. Department of Commerce reported that Americans doubled their use of fast Internet connections from 2001 to 2003 ("A Nation," 2004). This means that 20 percent of U.S.A. households now have a fast Internet connection. However, the Department of Commerce study would indicate that the majority of that growth is from individuals who already owned a computer and were previously connected to the Internet. Computer ownership during that same time period increased from 56.2 to 61.8 percent of households and Internet access increased from 50.3 to 54.6 percent ("A Nation," 2004).

Access to fast Internet is dependent on whether you live in a metro or rural area. Only 23.5 percent of rural Internet users had high-speed access compared to 39.8 percent for urban and 40.2 for central city ("A Nation," 2004). Other determining factors of Internet use are race/ethnicity, income, and education level. Sixty-five percent of the white population used the Internet, 45.6 percent of blacks and 37.2 percent of Hispanics ("A Nation," 2004). Less than 49 percent of those with income levels below $\$ 35,000$ used the Internet while greater that 62 percent of those with income levels above $\$ 35,000$ used the Internet ("A Nation," 2004). The survey also showed a relationship of income level and educational attainment. Only 15.5 percent of those with less than a high school education used the Internet while 44.5 percent of those with at least a high school diploma or GED did. Over 84.9 percent of those with a college degree used the Internet ("A Nation," 2004).

The assumption is that those individuals and families with a lower level of education and lower income potential most likely have an occupation that does not require computer and Internet use for the job and are less likely to have a computer in the home. However, one promising statistic is that 14.2 percent of U.S.A. Internet users do not have an Internet connection at home. This would indicate that they are able to access the Internet from work, public library, or from school. Another finding is that 41.3 percent of the U.S.A. population does not use the Internet ("A Nation," 2004).

\section{Classroom Use of Computers}

NTIA ("A Nation," 2002) reported a rate of computer use nearing 90 percent in kindergarten through high school (K-12). The National Center for Education Statistics (NCES) reported that by fall 2002, 99 percent of public schools had Internet access with 92 percent of their classrooms having access to the Internet ("Internet," 2003).

While there is some degree of computer use in almost all U.S.A. schools today, the amount and quality of availability varies greatly. Jackson, Ervin, Gardner, and Schmitt (2001) reviewed a number of studies and concluded that affluent mostly white students dominate classroom computer use and predominately use software that requires the use of critical thinking skills. Less affluent black and other minority students predominately use drill and practice software. There is reason to suspect that use is limited in scope in schools in low-income areas and that supplementary use, beyond that provided at school is necessary if students are to integrate computer use into their daily lives by the time they complete high school. 
Because of the perception that virtually all students have been exposed to computer and Internet usage by the time they complete high school, colleges and universities have increasingly treated fundamental computer skills as a required or a remedial skill. Students at the University of Dayton are expected to effectively use information technology and become life-long learners on the use of information technology (University of Dayton, 2003). North Carolina Public Schools instituted a computer proficiency requirement starting with 2001 graduates (Public Schools of North Carolina, 2001).

Besalel (2004) states that, "technology in the classroom directly contributes to student achievement, both by making students more effective in their learning and teachers more efficient in their teaching." Besalel (2004) also indicates that even using a computer for drill and repetition activities can be beneficial. Students in the primary grades are able to use software to reinforce math and spelling skills. The computer software provides for reinforcement and makes it "competitive and fun" (Besalel, 2004). Attewell (2001) also states that drill-and-practice software has been shown to improve reading, writing, and math skills. However Attewell (2001) also feels that the drill-and-practice use must be supplemented with other activities involving critical thinking. In some cases use of drill-and-practice software was based on ethnic and income background. Jackson, Ervin, Gardner, and Schmitt (2001) found in their review of several studies that poor black and other minority students primarily used drill-and-practice software while more affluent white students used software that required use of critical thinking skills. Damarin (2000) states that all students must have "opportunities for knowledge construction in authentic learning activities and situations" to remove the divide (p. 18).

Besides the basic skills of math and spelling computers can be used to develop higher-level critical thinking skills. Students can use the Internet to find answers to questions instead of just memorizing a bunch of facts. Teachers are able to shift student learning from memorizing answers to questions to knowing how to find answers (Besalel, 2004). So students may start out using a computer to reinforce basic skills and find the experience rewarding and then switch to using the computer for higher level critical thinking skills of identifying information needed to answer questions and to conduct efficient searches for the needed information. Sharp (2001) indicates that students must be taught "how to use the information effectively and efficiently" (p.12).

To accomplish efficient and effective use of computers it is necessary to have an adequate number of computers and Internet access in the classroom. Saying that a school has Internet access is not an adequate measure. What is important is whether Internet access is available to students in the classroom. Rother (2004) in the Second Annual'Teachers Talk Tech' Survey, found that 81 percent of teachers feel that using computers in the classroom enhances student academic performance and 62 percent indicated computer use increased standardized test performance. These reports are positive, but two out of three teachers participating in the survey indicated that the student-to-computer ratio was too high (Rother, 2004). The NCES ("Internet," 2003) reported the ratio of students to Internet connected instructional computers was greater for those schools from areas of the highest level of poverty.

Another problem is that money is being spent on computer technology but it becomes obsolete before teachers are trained how to use it. Public schools in Fort Worth, Texas, have spent over $\$ 40$ million to move their schools into the $21^{\text {st }}$ century, however, some teachers are still not trained in e-mail, Internet and other appropriate use of the technology (Berand, 2004). Teachers are either not using the computers or not using it to their potential because they are not comfortable without proper training (Berand, 2004). Rother (2004) reported that 48 percent of the teachers surveyed indicated that obtaining and maintaining computer hardware and software skills was an extremely to very serious problem. Rother (2003) states that, "realization is growing that even the most advanced technology is useless without trained teachers." Rother (2003) also believes 
that, "teacher education should not focus on technology alone, but on its alignment with curriculum."

\section{Home Use of Computers and Internet}

The NCES ("Teacher," 2000) found that 85 percent of young public school children with home computer access used them for educational purposes. Students with higher family social and economic status (SES) were more likely to use a home computer for educational purposes. The NCES ("Teacher," 2000) also found that students from families with lower SES and those who did not have home computer access were more likely to attend schools that did not have Internet access. NCES reported that 77 percent of whites have a home computer while only 41 percent of blacks and Hispanics have a computer in the home ("Computer," 2003). The NCES study also found that white students are almost twice as likely to use a home computer for school assignments as compared to black and Hispanic students (52, 28, and 27 percent respectively) ("Computer," 2003). Minority and disadvantaged kindergarten and first grade students have less access to a computer in the home ("Teacher," 2000). An encouraging finding by Attewell (2001) is that "at higher levels of income and education, there are minimal ethnic or racial differences in Internet access or computer ownership" (p. 253). One would hope that the divide would disappear if universal access was available for families at all income levels. However, societal reinforcement for computer and Internet use may not be the same for different levels of income.

\section{Societal Implications}

As we progress further into the $21^{\text {st }}$ Century and the information age, computer and Internet access becomes even more necessary. Evidence suggests that workers who use computers and who work in industries with extensive computer use tend to receive higher wages (Autor, Katz, \& Krueger, 1998). In addition, Internet use is becoming increasingly central to daily life as it provides information about social and health services, job opportunities, and the like. It is clearly important that young people incorporate computer and Internet usage into their daily lives.

Some scholars believe that those without technology skills will not have access to quality jobs, educational opportunities, and information that will be necessary for full and knowledgeable participation in our democratic and political environment (Adams, 2001; Attewell, 2001; Yoder, 2001). Kretchmer and Carveth (2001) state that we need to find a way to assist African Americans to overcome the digital divide so that they to can share in the "social, economic, political, and cultural promise and power" of computer and Internet access (p. 12). Without equal access how can we have e-voting? Local, state and federal government agencies are making more information and services available to citizens over the Internet. Damarin (2000) asks, if our schools are responsible for making future citizens familiar with tools and technologies that affect our social, cultural, political and economic environment? If it is the responsibility of our public schools we will need to address societal differences in the use of computers and the Internet based on how different groups perceive information to be valued and relevant (Attewell, 2001; Jackson, Ervin, Gardner, \& Schmitt, 2001; Simon, 2001).

\section{Purpose of Study}

This study examines factors that influence the rate of use of computer and Internet use outside of school by elementary and secondary school aged children, hereafter non-school use. Outside of school use is defined as any use of the computer or Internet access other than use at school during school hours. We focus on non-school use for two reasons. 1) several of the studies cited in the literature review have suggested that the extent computer use in school varies greatly, so that, use at school does not necessarily provide adequate grounding in the use of computer technology, and 
2) we would expect that students who are receiving an adequate grounding in computer and Internet use would tend to incorporate it into their lives by using the computer outside of school as well.

Summary statistics showing the distribution of the dependent variable and the distribution of all the independent variables used in our analysis are presented in Table 1 below. The independent variables that are expected to influence the rate of non-school computer use by students can be grouped into three main types:

1. Demographic characteristics of the students or their households that impact their rate of non-school computer use and may reflect limitations on access to computer outside of the classroom.

These include: the sex and ethnicity of the student and the geographic location, size and income level of the household, as well as the number of students in the household.

Ethnicity, location, and household income have been identified as factors influencing access to computers and the Internet in many of the studies cited above. In general, ethnic minorities, residents of remote rural locations or central cites and households with lower income levels have been found to have lower rates of computer use. Household size is included because, at any given income level, a larger household size may mean less discretionary income that can be used to provide access to computers. The number of students in the household is included with the thought that a larger number of students may provide a greater incentive to provide computer access.

2. Characteristics of parents or other adult household members that are likely to influence their student's non-school computer use.

These include: the highest education level of adult household members, whether any adults in the house hold use a computer at work, and the highest rate of computer use among the industries in which adult household members work.

As education level increases, adults are more likely to use and own computers. We hypothesize that this carries over to providing more opportunities for their students to use the computer and providing greater modeling of the importance of computer use. Similarly, use of a computer at work provides added incentive for computer ownership and increased likelihood that students may receive modeling and mentoring of computer use from adults in their household. The third characteristic is included under the hypothesis that adults working in an industry where computers are widely used will have a greater appreciation for the importance of computer skills and will be more likely to provide their students with opportunities and encouragement to use the computer.

3. Characteristics of the students' school experience.

Specifically does the student use a computer at school, during school hours?

This characteristic is designed to capture the impact of use of computers in class on the students' non-school computer use. We hypothesize that use of a computer in school will tend to increase non-school computer use. In a sense this variable provides a means of assessing the effectiveness of school computer use. If the level of use in school use is adequate to provide a reasonable level of proficiency, we would expect to see a rather substantial positive impact on the rate of non-school use.

\section{The Data Set}

The analysis is based on data from a survey of computer use that is conducted jointly by the U.S. Department of Labor Statistics and the Census Bureau. The most recent computer use survey was 
conducted in October 2003 and includes just over 22,000 individuals aged 6 through 18 who are students in elementary and high schools. (Students under 18 who are attending college are not included). Nearly all of the survey data are reported in sets of categories. To facilitate analysis, we have consolidated some categories to provide the sets of ranges shown in Table 1. With respect to race and ethnicity groups, the race category in the survey identifies individuals as white, black, American Indian, Asian, or of mixed race. Persons of Hispanic origin may also be in any of these racial categories. For the purposes of this study, an additional Hispanic ethnicity category was added. Only white Hispanics were placed in the Hispanic category, while those who are Hispanic and black were placed in the black category, and so on.

Assessing the impact of adult household members on students is complicated by the fact that there may be several adults in the household. In order to assess the impact of adult household members without dealing with all of the complexities of varied household sizes and configurations, we focus on the maximum level of each influencing characteristic possessed by any adult in the household. We use the highest level of educational attainment among adult members of the household as our measure of educational level for the household. In a similar fashion, to assess the impact of adults' computer use at work, we use a dummy variable that is set to one if at least one person in the household uses the computer at work and a zero otherwise. In addition to this impact of direct use, we have hypothesized that adults who see computers being used extensively in their work environment will have more incentive to encourage computer use by their students. To measure this, we compute the average computer use at work by industry based upon a detailed set of 52 industry categories reported in the survey. (Where there were fewer than 50 workers in a given industry similar categories were combined.) The average use in the industry in which each adult worked was then added to their individual data and, as with the education data, the highest level of computer use among the industries in which the adults of the household worked was recorded as our measure of this effect.

As noted earlier, in-class computer use is also used as an independent variable since one would expect that in-school use should encourage non-school use. In-class computer use is simply measured as a dummy variable that is 1 if a student used the computer at school and a 0 otherwise. The survey did not provide any measure of the extent of use.

The dependent variable for this study is also a dichotomous variable which is recorded as a one if a student reported using the computer in any context other than at school during school hours and a zero if they did not. The survey asked if students used a computer at home, if they used the Internet at a library or community center, at a friend's home, or at any other non-school location. Students were also asked if they used a computer at school outside of school hours. If they answered yes to any of these questions, they were recorded as having non-school use of a computer.

Table 1: Distribution of the Dependent and Independent Variables

\begin{tabular}{|cccc|}
\hline Distribution of Categorical Variables & & & \\
Student Non-School Computer Use & Count & $\begin{array}{c}\text { Percentage } \\
\text { in Category }\end{array}$ & \\
No & 4586 & $21.71 \%$ & \\
Yes & 16539 & $78.29 \%$ & $\begin{array}{c}\text { Non-School } \\
\text { Computer Use } \\
\text { Rate in Category }\end{array}$ \\
\hline
\end{tabular}




\begin{tabular}{|c|c|c|c|}
\hline \multicolumn{4}{|l|}{ Household Characteristics } \\
\hline \multicolumn{4}{|l|}{ Region } \\
\hline Northeast & 4252 & $20.13 \%$ & $83.42 \%$ \\
\hline Midwest & 5413 & $25.62 \%$ & $81.99 \%$ \\
\hline South & 5807 & $27.49 \%$ & $73.02 \%$ \\
\hline West & 5653 & $26.76 \%$ & $76.31 \%$ \\
\hline \multicolumn{4}{|l|}{ Location Type } \\
\hline Central City & 4221 & $19.98 \%$ & $69.18 \%$ \\
\hline Suburban (or Unknown) & 11648 & $55.14 \%$ & $81.62 \%$ \\
\hline Rural & 5256 & $24.88 \%$ & $78.23 \%$ \\
\hline \multicolumn{4}{|l|}{ Race/Ethnicity } \\
\hline White - Non-Hispanic & 16863 & $79.82 \%$ & $81.52 \%$ \\
\hline Black & 2538 & $12.01 \%$ & $58.43 \%$ \\
\hline Native American & 307 & $1.45 \%$ & $57.00 \%$ \\
\hline Asian & 634 & $3.00 \%$ & $79.81 \%$ \\
\hline White - Hispanic & 2848 & $13.48 \%$ & $59.02 \%$ \\
\hline Mixed Race & 783 & $3.71 \%$ & $80.33 \%$ \\
\hline \multicolumn{4}{|l|}{ Income Level } \\
\hline Less than $\$ 15,000$ & 2573 & $12.18 \%$ & $52.70 \%$ \\
\hline$\$ 15,000-\$ 30,000$ & 3455 & $16.36 \%$ & $63.56 \%$ \\
\hline$\$ 30,000-\$ 50,000$ & 4781 & $22.63 \%$ & $78.48 \%$ \\
\hline$\$ 50-000-\$ 75,000$ & 4437 & $21.00 \%$ & $85.78 \%$ \\
\hline Over $\$ 75,000$ & 5879 & $27.83 \%$ & $92.35 \%$ \\
\hline \multicolumn{4}{|l|}{ Student Characteristics } \\
\hline \multicolumn{4}{|l|}{ Sex } \\
\hline Male & 10812 & $51.18 \%$ & $77.52 \%$ \\
\hline Female & 10313 & $48.82 \%$ & $79.10 \%$ \\
\hline \multicolumn{4}{|l|}{ Parent/Adult Characteristics } \\
\hline \multicolumn{4}{|l|}{ Highest Education Level } \\
\hline HS or Less & 6759 & $32.00 \%$ & $61.37 \%$ \\
\hline Some College & 6989 & $33.08 \%$ & $81.07 \%$ \\
\hline College Graduate & 4613 & $21.84 \%$ & $90.16 \%$ \\
\hline
\end{tabular}




\begin{tabular}{|cccc|}
\hline Graduate Degree & 2764 & $13.08 \%$ & $92.84 \%$ \\
Use Computer at Work & & & \\
No & 7889 & $37.34 \%$ & $61.93 \%$ \\
Yes & 13236 & $62.66 \%$ & $88.04 \%$ \\
School Characteristics & & & \\
Computer Used at School & & & $58.71 \%$ \\
No & 2567 & $12.15 \%$ & $81.00 \%$ \\
Yes & 18558 & $87.85 \%$ & \\
Distribution of Values of Quantitative Variables & & \\
& & Standard & \\
Number of Persons in Household & 4.485 & Deviation & \\
Number of Students in Household & 2.226 & 1.428 & \\
Computer Use in Workers Industry & 0.566 & 0.221 & \\
\hline
\end{tabular}

Average values for the dependent variable within each category of the independent variables are listed in the last column of Table 1 above. Non-school computer use increases with increased income and adult education levels as we would expect. The data for the ethnicity of the student also shows substantial differences, with black, Native American, and White Hispanic students showing non-school computer use rates between 20 and 25 percent below those of white non-Hispanic students. Also noteworthy is the strong differential between those who use a computer at school and those who do not. On average, students using a computer at school are over 20 percent more likely to use a computer outside of class as well.

Correlation analysis of the independent variables, not presented in detail here, shows that intercorrelations for most of the variables are in the low to moderate range. Only two combinations of variables have a correlation rate greater than .5; the correlation between the set of income categories and the set of education categories is .54 and the correlation between household size and the number of students in the household is .72. Coefficients for these variables should be interpreted somewhat cautiously because of their relatively high multi-colinearity.

\section{The Logit Regression Procedure}

Because our analysis uses a dichotomous dependent variable, standard linear regression is not appropriate. It produces an error term that cannot be normally distributed. The Logit function is a commonly used technique that produces maximum likelihood estimates for equations with dichotomous dependent variables (Green, 1997). The Logit function essentially uses the log of the odds ratio (the ratio of the probabilities of the two outcomes of a dichotomous variable) as the dependent variable and performs a "standard" linear regression on this transformed value. In our case the odds ratio is the probability of a student using a computer outside of school divided by the probability of the student not using a computer outside of school. This is illustrated in equation 1 where $\ln$ is the natural logarithm, $\mathrm{p}_{\mathrm{cu}}$ is the probability of using the computer, a is an intercept term, $\mathrm{X}$ is a vector of independent variables, $\mathrm{B}$ is a vector of coefficients on those variables and $\mathrm{e}$ is the error term. The antilog of equation 1 yields equation 2. 


$$
\begin{aligned}
& \ln \left(\mathrm{p}_{\mathrm{jc}} /\left(1-\mathrm{p}_{\mathrm{cu}}\right)\right)=\mathbf{a}+\mathbf{B X}+\mathrm{e} \\
& \mathrm{p}_{\mathrm{cu}} /\left(1-\mathrm{p}_{\mathrm{cu}}\right)=\exp \mathbf{x} \exp \mathbf{B} \mathrm{x} \operatorname{expX} \times \exp \mathrm{e}
\end{aligned}
$$

The B coefficients in equation 2 can be interpreted as percentage changes in the odds-ratio of the dependent variable, and this interpretation is appropriate for the coefficients of our analysis. If the probability of non-school computer use by a student with given characteristics is 80 percent, their odds ratio would be $.8 / .2$ or 4 , if the probability is .5 the odds ratio is $.5 / .5$ or 1 , and if the probability is .25 the odds ratio is $.2 / .8$ or $1 / 4$. Coefficients must be interpreted cautiously since the magnitude of their impact varies as the mean probability of an event varies.

\section{Model Results}

Table 2 below presents the empirical results of the model. Logistic regression does not produce standard R-Square type measures of fit. Rather, a series of Chi-Square statistics are generated for the overall fit of the model and for the coefficients of the individual independent variables. The model was statistically significant at the .001 level with respect to the overall model. For the categorical independent variables, a series of dummy variables are used in the regression with one category being left out to serve as the base category. To facilitate understanding, the base category in each classification is included in the results of Table 2, but with a dash where the coefficient would have been. Thus, in interpreting the results for the Region categories, the Northeast region is the excluded category and the coefficients for the other regions represent differences in the odds of non-school computer use for residents of each of the other regions as compared to residents of the Northeast. The results suggest that residents of each of the other regions are slightly, but significantly less likely to use computers outside of school. Coefficients which are significantly different from zero at the .05 level of probability are indicated by an asterisk.

Table 2. Factors Determining Student Use of Computers Outside of Class

\begin{tabular}{|c|c|c|c|}
\hline & Coefficient & $\begin{array}{l}\text { Chi-Square } \\
\text { Probability }\end{array}$ & \\
\hline Intercept & 1.6103 & $<.0001$ & $*$ \\
\hline \multicolumn{4}{|l|}{ Household Characteristics } \\
\hline \multicolumn{4}{|l|}{ Region } \\
\hline \multicolumn{4}{|l|}{ Northeast } \\
\hline Midwest & -0.1949 & 0.0013 & $*$ \\
\hline South & -0.3451 & $<.0001$ & $*$ \\
\hline West & -0.2998 & $<.0001$ & $*$ \\
\hline \multicolumn{4}{|l|}{ Location Type } \\
\hline Central City & -0.0824 & 0.0918 & \\
\hline \multicolumn{4}{|l|}{ Suburban (or Unknown) } \\
\hline Rural & 0.0209 & 0.6596 & \\
\hline
\end{tabular}
(as measured by the log odds ratio of student non-class computer use) 


\begin{tabular}{|c|c|c|c|}
\hline Income Level & & & \\
\hline Less than $\$ 15,000$ & -1.0538 & $<.0001$ & $*$ \\
\hline$\$ 15,000-\$ 30,000$ & -0.8766 & $<.0001$ & $*$ \\
\hline$\$ 30,000-\$ 50,000$ & -0.4488 & $<.0001$ & * \\
\hline$\$ 50-000-\$ 75,000$ & -0.2943 & $<.0001$ & $*$ \\
\hline \multicolumn{4}{|l|}{ Over $\$ 75,000$} \\
\hline \# of Persons in Household & -0.1315 & $<.0001$ & $*$ \\
\hline \# of Students in Household & 0.1151 & $<.0001$ & $*$ \\
\hline \multicolumn{4}{|l|}{ Student Characteristics } \\
\hline \multicolumn{4}{|l|}{ Race/Ethnicity } \\
\hline \multicolumn{4}{|l|}{ White - Non-Hispanic } \\
\hline Black & -0.8806 & $<.0001$ & $*$ \\
\hline Native American & -0.7733 & $<.0001$ & * \\
\hline Asian & -0.1238 & 0.2796 & \\
\hline White - Hispanic & -0.6544 & $<.0001$ & $*$ \\
\hline Mixed Race & -0.0959 & 0.345 & \\
\hline \multicolumn{4}{|l|}{ Sex } \\
\hline \multicolumn{4}{|l|}{ Male } \\
\hline Female & 0.1167 & 0.0013 & $*$ \\
\hline \multicolumn{4}{|l|}{ Parent/Adult Characteristics } \\
\hline \multicolumn{4}{|l|}{ Highest Education Level } \\
\hline HS or Less & -0.822 & $<.0001$ & $*$ \\
\hline Some College & -0.2995 & $<.0001$ & $*$ \\
\hline \multicolumn{4}{|l|}{ College Graduate } \\
\hline Graduate Degree & 0.1338 & 0.1491 & $*$ \\
\hline Use Computer at Work & 0.5789 & $<.0001$ & $*$ \\
\hline Comp. Use in Workers Industry & 0.4119 & $<.0001$ & $*$ \\
\hline \multicolumn{4}{|l|}{ School Characteristics } \\
\hline \multicolumn{4}{|l|}{ Computer Used at School } \\
\hline \multicolumn{4}{|l|}{ No } \\
\hline Yes & 1.039 & $<.0001$ & * \\
\hline
\end{tabular}


With respect to other household demographic factors, results are mixed. Neither rural nor central city locations have statistically significant impact on non-school use as compared to the base Suburban residence category. As expected, household income does influence the rate of nonschool student computer use with higher income leading to great odds of use. In relative terms, the magnitude of this impact is substantially greater for the income categories below $\$ 30,000$. The household size and number of students in the household do have statistically significant impacts in the direction that was hypothesized, although the magnitude of their effects is relatively small.

As expected, the ethnicity of the student is found to have a significant impact on the odds of nonschool computer use. Two of the ethnicity categories, Asian Americans and those of mixed race were not found to be significantly different from the white non-Hispanic base category. However, the other three categories - black, Native American, and White Hispanic - show a substantial decrease in the odds of non-school computer use as compared to the base category and the coefficient for these three categories are remarkably similar to each other. The student's gender is also found to have a small but significant impact with female students being slightly more likely to have non-school computer use.

Characteristics of parents and other adult household members have effects that are consistent with our hypotheses. For the education level variable, the coefficient for those with a high school education or less is most striking. There seems to be a rather substantial gap between households with no adult that has any education beyond high school and households where there has been at least some college attendance. Having an adult household member who uses the computer at work and having a household member working in an industry where computers are used extensively are also shown to have a significant positive impact on non-school computer use by students.

Finally use of a computer at school was found to have the expected positive impact on non-school computer use. The coefficient for this variable was highly significant and its magnitude rather large in relationship to many of the other independent variables.

\section{Estimating the Magnitude of Impacts}

The results above are interesting and support our hypotheses with respect to factors influencing student use of computers outside the classroom. However, due to the difficulty of interpreting logistic regression coefficients it is hard to get a feel for the magnitude of the effect of the various independent variables. One way to get a sense of the magnitude of various effects is to generate predicted rates of non-school student computer use for students with differing characteristics. Fundamentally this process involves adding up the appropriate coefficients, calculating the anti$\log$ of the result and then converting from an odds ratio to a predicted probability of use.

Table 3 presents a comparison of the expected probability of non-school computer use for two very extreme cases. The Very High Probability User is a white female student who lives in the Northeast in a household with an income of over $\$ 75,000$. In addition adults in this student's household hold a graduate degree, use a computer at work and work in an industry where 80 percent of workers use a computer. Finally, this student also uses a computer at school. In contrast the Very Low Probability User is a black male student living in the South in a household with less than $\$ 15,000$ in income containing no adults with more than a high school education and no one who uses a computer at work or works in an industry where computers are used. In addition this student does not use a computer at school. While the two alternative cases are, admittedly, very extreme, the difference in the probability of non-school use is remarkable. The very high probability user is almost certain to be a non-school computer user, while the very low probability user is extremely unlikely to use one and there is a difference of almost $85 \%$ in their relative 
probabilities of non-school computer use. The bottom portion of Table 3 examines the contributions of the various independent variables to these differences. Note that use of a computer at school is the largest single factor with the education and income level differentials and the difference in race following close behind. The other major factor was the impact of the work experience of adult household members. If the effects of using a computer at work and working in an industry with high computer use are added together, this factor is about equal to the race education and income level effects.

Table 3. Probability of Non-School Computer Use - Very Likely vs. Very Unlikely Users

\begin{tabular}{|c|c|c|c|}
\hline & $\begin{array}{c}\text { Very High } \\
\text { Probability User }\end{array}$ & $\begin{array}{c}\text { Very Low } \\
\text { Probability User }\end{array}$ & $\begin{array}{l}\text { Difference in } \\
\text { Probabilities }\end{array}$ \\
\hline $\begin{array}{l}\text { Probability of Use Outside } \\
\text { of School }\end{array}$ & $96.76 \%$ & $12.08 \%$ & $84.68 \%$ \\
\hline \multicolumn{4}{|c|}{ Source of Differences in Probability of Use } \\
\hline & $\begin{array}{c}\text { Very High } \\
\text { Probability User }\end{array}$ & $\begin{array}{c}\text { Very Low } \\
\text { Probability User }\end{array}$ & $\begin{array}{l}\text { Contribution to } \\
\text { Difference in } \\
\text { Probabilities }\end{array}$ \\
\hline \multicolumn{4}{|l|}{ Demographic Characteristics } \\
\hline Region & Northeast & South & $5.61 \%$ \\
\hline Location Type & Suburban & Central City & $1.34 \%$ \\
\hline Race/Ethnicity & White & Black & $14.33 \%$ \\
\hline Income Level & More than $\$ 75,000$ & Less than $\$ 15,000$ & $14.26 \%$ \\
\hline \multicolumn{4}{|l|}{ Student Characteristics } \\
\hline Sex & Female & Male & $1.90 \%$ \\
\hline \multicolumn{4}{|l|}{ Parent/Adult Characteristics } \\
\hline Highest Education Level & Graduate Degree & $\begin{array}{l}\text { High School or } \\
\text { Less }\end{array}$ & $15.55 \%$ \\
\hline Use Computer at Work & Yes & No & $9.42 \%$ \\
\hline $\begin{array}{l}\text { Rate of Computer Use in } \\
\text { Workers Industry }\end{array}$ & 80 Percent & None & $5.36 \%$ \\
\hline \multicolumn{4}{|l|}{ School Characteristics } \\
\hline Computer Used at School & Yes & No & $16.90 \%$ \\
\hline
\end{tabular}

The comparison in Table 3 was designed to provide the strongest possible contrast between groups and thus used combinations of characteristics that are extremely uncommon. Table 4 provides a more representative set of contrasts. Both the moderately high probability user and the moderately low probability user are assumed to be female students living in the suburbs and both 
are assumed to use a computer at school. The remaining assumed characteristics for the two alternative students are as summarized in the bottom portion of Table 4 . The differences in probabilities of non-school computer use are substantially smaller for this case. However, nearly a third of students with the characteristics of the Moderately Low Probability User do not use a computer outside of class. In this example, ethnicity and computer use at work by an adult household member are the most important factors. The variables found to be most important are to a substantial degree a function of the specific example chosen. However, the example of Table 4 does illustrate that students with relatively common sets of characteristics may have predicted rates of non-school computer use that lag substantially behind use rates for the highest probability users.

Table 4. Probability of Non-School Computer Use Moderately Likely vs. Moderately Unlikely Users

\begin{tabular}{|c|c|c|c|}
\hline & $\begin{array}{l}\text { Moderately High } \\
\text { Probability User }\end{array}$ & $\begin{array}{l}\text { Moderately Low } \\
\text { probability User }\end{array}$ & $\begin{array}{l}\text { Difference in } \\
\text { Probabilities }\end{array}$ \\
\hline $\begin{array}{l}\text { Probability of Use Outside } \\
\text { of School }\end{array}$ & $94.10 \%$ & $68.23 \%$ & $25.87 \%$ \\
\hline \multicolumn{4}{|c|}{ Source of Differences in Probability of Use } \\
\hline & $\begin{array}{l}\text { Moderately High } \\
\text { Probability User }\end{array}$ & $\begin{array}{l}\text { Moderately Low } \\
\text { probability User }\end{array}$ & $\begin{array}{c}\text { Contribution to } \\
\text { Difference in } \\
\text { Probabilities }\end{array}$ \\
\hline \multicolumn{4}{|l|}{ Demographic Characteristics } \\
\hline Region & Northeast & Midwest & $2.51 \%$ \\
\hline Race/Ethnicity & White & White - Hispanic & $8.44 \%$ \\
\hline Income Level & $\$ 50,000$ to $\$ 75,000$ & $\$ 30,000$ to $\$ 50,000$ & $1.99 \%$ \\
\hline \multicolumn{4}{|l|}{ Parent/Adult Characteristics } \\
\hline Highest Education Level & College Degree & Some College & $3.86 \%$ \\
\hline Use Computer at Work & Yes & No & $7.47 \%$ \\
\hline $\begin{array}{l}\text { Rate of Computer Use in } \\
\text { Workers Industry }\end{array}$ & 60 Percent $\%$ & 30 Percent & $1.59 \%$ \\
\hline
\end{tabular}

The results in Tables 3 and 4 also shed some light on the digital divide versus digital differences controversy. Ethnicity does have an impact on the rates of non-school use found in Tables 3 and 4 , but, the magnitude of this impact is substantially smaller than the direct difference in nonschool computer use rates across ethnicity categories that were identified in Table 2. It appears that a substantial portion of the observed differences in non-school computer use across ethnicity are due to factors that might be described as differences in accessibility to computer use - as suggested by those arguing that there is a digital divide. Specifically, black Native American, and Hispanic households generally have lower average education and average income levels than the white non-Hispanic base group and also have lower average rates of working in industries where computers are used extensively or of using a computer themselves at work. 


\section{Non-School Computer Use by Age Category of the Student}

In the analysis thus far, we have combined students in the entire age range from 6 to 18 in a single group. There are good reasons to suspect that there may be differences in the factors motivating computer use by elementary school (6 to 11 year old) students and the factors that impact secondary school (12 to 18 year old) students. To examine these potential differences we divided our sample into the two age groups described above and estimated our base model for each group. These results are presented in Table 5. For the most part the coefficients in Table 5 show remarkable stability across the age categories. However, some differences are noteworthy. The gender differential is substantially larger for the older age category and in fact the gender difference is not significant in the younger age groups. In addition, the impact of computer use at school on non-school use is slightly less among the older age group. Finally, the coefficient for the rate of computer use in industries where adult household members work is not statistically significant for the 6 to 11 year old group, but becomes much larger and highly significant for the 12 to 18 year old group. This may suggest that career modeling becomes a factor for secondary school students.

Table 5. Factors Determining Student Use of Computers Outside of Class by Age Group (as measured by log odds ratio of student using a computer outside of class)

\begin{tabular}{|c|c|c|c|c|c|c|}
\hline & Coefficient & $\begin{array}{l}\text { Chi-Square } \\
\text { Probability }\end{array}$ & & Coefficient & $\begin{array}{l}\text { Chi-Square } \\
\text { Probability }\end{array}$ & \\
\hline Intercept & 1.3215 & $<.0001$ & $*$ & 1.9758 & $<.0001$ & $*$ \\
\hline \multicolumn{7}{|l|}{ Household Characteristics } \\
\hline \multicolumn{7}{|l|}{ Region } \\
\hline \multicolumn{7}{|l|}{ Northeast } \\
\hline Midwest & -0.2473 & 0.002 & $*$ & -0.1299 & 0.1754 & \\
\hline South & -0.3674 & $<.0001$ & $*$ & -0.3507 & $<.0001$ & $*$ \\
\hline West & -0.2984 & 0.0002 & $*$ & -0.3383 & 0.0003 & $*$ \\
\hline \multicolumn{7}{|l|}{ Location Type } \\
\hline Central City & -0.0732 & 0.2667 & & -0.0849 & 0.2582 & \\
\hline \multicolumn{7}{|l|}{$\begin{array}{l}\text { Suburban (or un- } \\
\text { known) }\end{array}$} \\
\hline Rural & 0.0387 & 0.546 & & -0.0216 & 0.7666 & \\
\hline \multicolumn{7}{|l|}{ Income Level } \\
\hline Less than $\$ 15,000$ & -1.0489 & $<.0001$ & $*$ & -0.9949 & $<.0001$ & $*$ \\
\hline$\$ 15,000-\$ 30,000$ & -0.8461 & $<.0001$ & $*$ & -0.8458 & $<.0001$ & $*$ \\
\hline$\$ 30,000-\$ 50,000$ & -0.339 & 0.0002 & $*$ & -0.5274 & $<.0001$ & $*$ \\
\hline$\$ 50-000-\$ 75,000$ & -0.3366 & 0.0002 & $*$ & -0.2151 & 0.0597 & \\
\hline \multicolumn{7}{|l|}{ Over $\$ 75,000$} \\
\hline \# of Persons in Household & -0.1316 & $<.0001$ & $*$ & -0.1116 & 0.0002 & $*$ \\
\hline
\end{tabular}




\begin{tabular}{|c|c|c|c|c|c|c|}
\hline \# of Students in Household & 0.1819 & $<.0001$ & $*$ & 0.0401 & 0.319 & \\
\hline \multicolumn{7}{|l|}{ Student Characteristics } \\
\hline \multicolumn{7}{|l|}{ Race/Ethnicity } \\
\hline \multicolumn{7}{|c|}{ White-Non-Hispanic } \\
\hline Black & -0.8664 & $<.0001$ & $*$ & -0.9381 & $<.0001$ & $*$ \\
\hline Native American & -0.7231 & 0.0002 & $*$ & -0.8846 & $<.0001$ & $*$ \\
\hline Asian & -0.2207 & 0.1228 & & 0.1143 & 0.5623 & \\
\hline White - Hispanic & -0.6258 & $<.0001$ & $*$ & -0.6638 & $<.0001$ & $*$ \\
\hline Mixed Race & -0.1432 & 0.2588 & & 0.1381 & 0.4358 & \\
\hline \multicolumn{7}{|l|}{ Sex } \\
\hline \multicolumn{7}{|l|}{ Male } \\
\hline Female & 0.0545 & 0.279 & & 0.1873 & 0.0012 & $*$ \\
\hline \multicolumn{7}{|l|}{ Parent/Adult Characteristics } \\
\hline \multicolumn{7}{|l|}{ Highest Education Level } \\
\hline HS or Less & -0.9745 & $<.0001$ & $*$ & -0.7123 & $<.0001$ & $*$ \\
\hline Some College & -0.4257 & $<.0001$ & $*$ & -0.1725 & 0.0868 & \\
\hline \multicolumn{7}{|l|}{ College Graduate } \\
\hline Graduate Degree & -0.00383 & 0.9734 & & 0.4119 & 0.0117 & $*$ \\
\hline Use Computer at Work & 0.5901 & $<.0001$ & $*$ & 0.6266 & $<.0001$ & $*$ \\
\hline $\begin{array}{l}\text { Comp. Use in } \\
\text { Workers Industry }\end{array}$ & 0.241 & 0.0635 & & 0.5532 & 0.0001 & $*$ \\
\hline \multicolumn{7}{|l|}{ School Characteristics } \\
\hline \multicolumn{7}{|l|}{ Computer Used at School } \\
\hline \multicolumn{7}{|l|}{ No } \\
\hline Yes & 1.0665 & $<.0001$ & $*$ & 0.8636 & $<.0001$ & $*$ \\
\hline
\end{tabular}

\section{Conclusion}

Based on the analysis of our results we can state that geographic region of the country, increased income, household size and number of students in the household, education level of adult members of the family, ethnic background, and school use of a computer impact non-school computer use. The ethnic results show white, Asian Americans, and mixed race are more likely to have non-school use of a computer than black, Native American, and white-Hispanic.

An interesting result is that female students are more likely to have non-school computer use than males. In the past and currently the computer industry is a male dominated profession. This might be an indication of future changes in gender-based differences for computer professionals. Level of education is shown to have a significant impact particularly those with a high school education 
or less and those with at least some college. Adult family member use of a computer on the job or in an industry where computer use is extensive also showed a positive impact on non-school computer use. As expected using a computer in school showed a large positive impact on nonschool use of a computer. This would indicate that we need to continue to encourage increased school use of computers to properly prepare future voters for a computer and Internet dominated social and political environment.

An important limitation of this study is the fact that it does not contain any measures of the intensity of use either within the classroom or in the non-school computer use dependent variable. Assessment of the impact of the extent and type of computer use in the class room on students computer use outside of class and on their preparedness for college level study is an important topic for further research suggested by the results of this study.

\section{References}

Adams, A. R. (2001). Introduction: Beyond numbers and demographics: "Experience-Near" explorations of the digital divide. ACM SIGCAS Computers and Society, 31 (3), 5-8.

Attewell, P. (2001). The first and second digital divides. Sociology of Education, 74, 252-259.

Autor, D., Katz, L., \& Krueger, A. (1998). Computing inequality: Have computers changed the labor market? Quarterly Journal of Economics, 113, 1169-1212.

Berand, Y. (2004). Shorting out. Retrieved March 25, 2004, from http://www.dfw.com/mld/dfw/news/local/8247085.htm

Besalel, S. (2004). Technology's impact on academic achievement. Retrieved February 12, 2004, from http://www.thejournal.com/thefocus/33.cfm

Compaine, B. Ed. (2001). The Digital Divide Facing a Crisis or Creating a Myth, Cambridge, Mass: MIT Press.

Computer and Internet use by children and adolescents in 2001. (2003). Washington, DC: National Center for Education Statistics. Retrieved February 11, 2005, from http://nces.ed.gov/pubs2004/2004014.pdf

Damarin, S. K. (2000). The 'Digital Divide' versus digital differences: Principles for equitable use of technology in education. Educational Technology. 40 (4), 17-22.

'Digital Divide' still an issue, consumer groups say. (2002). Retrieved May 30, 2002 from http://www.reuters.com/news article.jhtml:type=technologynews\&StoryID=1028453

Falling through the net: Defining the digital divide. (1999). Washington, DC: National Telecommunications and Information Administration. Retrieved December 12, 2004 from http://www.ntia.doc.gov/ntiahome/fttn99/FTTN.pdf

Falling through the net: Towards digital inclusion. (2000). Washington, DC: National Telecommunications and Information Administration. Retrieved December 12, 2004 from http://search.ntia.doc.gov/pdf/fttn00.pdf

Gootman, E. (2004). Inventory shows an uneven distribution of school computers. Retrieved April 14, 2004 , from http://www.nytimes.com/2004/04/03/education/03school.html?ex $=1082088000 \&$ en $=f 53 \mathrm{fe} 6 \mathrm{c} 3653 \mathrm{cf0c}$ $\underline{2 \& \mathrm{ei}=5070}$

Green, W. (1997). Econometric Analysis, $3^{\text {rd }}$ Edition. Upper Saddle River, NJ: Prentice Hall.

Internet access in U.S. public schools and classrooms: 1994-2002. (2003). Washington, DC: National Center for Education Statistics. Retrieved February 11, 2005, from http://nces.ed.gov/pubs2004/2004011.pdf 
Jackson, L. A., Ervin, K. S., Gardner, P. D., \& Schmitt, N. (2001). The racial digital divide: Motivational, affective, and cognitive correlates of Internet use. Journal of Applied Social Psychology, 31 (10), 2019-2046.

Kretchmer, S. B., \& Carveth R. (2001). The color of the net: African Americans, race, and cyberspace. ACM SIGCAS Computers and Society, 31 (3), 9-14.

Mack, R. (2001). Digital Divide: Standing at the intersection of race and technology. Durham, NC: Carolina Academic Press.

A nation online: Entering the broadband age. (2004). Washington, DC: National Telecommunications and Information Administration. Retrieved December 13, 2004, from

http://www.ntia.doc.gov/reports/anol/NationOnlineBroadband04.htm

A nation online: How Americans are expanding their use of the Internet. (2002). Washington, DC: National Telecommunications and Information Administration. Retrieved December 13, 2004 from http://www.ntia.doc.gov/ntiahome/dn/anationonline2.pdf

Public Schools of North Carolina. (2001). 2000-01 Report of student performance on NC tests of computer skills. Retrieved June 172004 from http://www.ncpublicschools.org/accountability/testing/computerskills/reports/cskillsrep00-01.pdf

Rother, C. (2003). Technology's value in education. Retrieved January 21, 2004 from http://www.thejournal.com/magazine/vault/A4576B.cfm

Rother, C. (2004). Evaluating technology's role in the classroom. T.H.E Journal Online. Retrieved February 14, 2005 from http://www.thejournal.com/magazine/vault/articleprintversion.cfm?aid=5038

Sharp, S. (2001). Bridging the digital divide. T.H.E. Journal, 28 (10), 10-12.

Simon, S. J. (2001). The impact of culture and gender on Web sites: An empirical study. The DATA BASE for Advances in information Systems, 32 (1), 18-37.

Teacher use of computers and the Internet in public schools. (2000). Washington, DC: National Center for Education Statistics. Retrieved December 13, 2004, from http://nces.ed.gov/pubsearch/pubsinfo.asp?pubid $=2000090$

University of Dayton. (2003). Undergraduate issue information technology facilities and services. The Bulletin. Retrieved August 13, 2004 from http://bulletin.udayton.edu/content.ud? $v=1 \& p=214 \& c=227$

Yoder, M. B. (2001). The digital divide: The problem and its implications. Learning \& Leading with Technology, 28 (5), 10-13, +50-51.

\section{Biography}

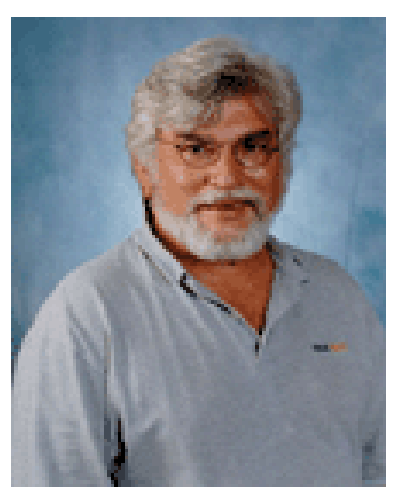

James N. Morgan: Professor of Computer Information Systems in the College of Business Administration at Northern Arizona University, Jim holds a doctoral degree in economics from the University of Missouri-Columbia. He has taught in the computer technology field for 20 years. His research has appeared in a variety of journals including: Information and Management, the Journal of Education for Business, and the Journal of Information Systems Education. He teaches Database Management, Application Development, and Management Information Systems classes. 


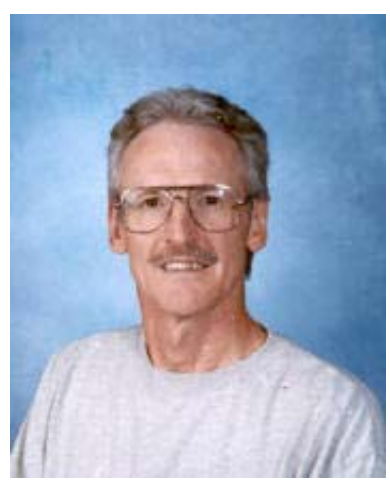

Craig A. VanLengen is an associate professor of computer information systems in the College of Business Administration at Northern Arizona University. He holds degrees with majors in accounting, information sciences, and educational computing and technology. His primary teaching responsibilities are in Web technology and development, systems analysis and design, introductory programming, and introduction to computer information systems. Current research interests are in CIS/MIS curriculum, Web development and use, human computer interaction, and computers and problem-solving. 